\title{
Saepo Modi and Correlation among Statistical Methods for Measuring of Phenotypic Stability
}

Saepo Modi dan Korelasi antarmetode Statistik untuk Mengukur Stabillitas Fenotipe

Sabam Malau ${ }^{1 *}$, Albiner Siagian ${ }^{2}$, Maria Rumondang Sihotang ${ }^{3}$, Rosnawyta Simanjuntak ${ }^{4}$, N.D.M. Romauli Hutabarat ${ }^{5}$

${ }^{1}$ Agroecotechnology Department, Agriculture Faculty, Universitas HKBP Nommensen, Jalan Sutomo 4-A, Medan 20234, Indonesia.

2 Public Health Department, Universitas Sumatera Utara, Jalan Abdul Hakim 1, Medan, Indonesia.

3 Agribusiness Department, Agriculture Faculty, Universitas HKBP Nommensen, Jalan Sutomo 4-A, Medan 20234, Indonesia.

${ }^{4}$ Technology of Agriculture Product Department, Agriculture Faculty, Universitas HKBP Nommensen, Jalan Sutomo 4-A, Medan 20234, Indonesia.

${ }^{5}$ Food Science and Technology, Faculty of Agriculture, Universitas Sumatera Utara, Jalan Jalan Prof A Sofyan 3, Medan, Indonesia.

*Corresponding author : sabam.malau@uhn.ac.id

\begin{abstract}
A stabile phenotype is desired. Many statistical methods are available to measure stability. So far, the choice of parameter of stability depended on the perception on the interaction of genotype and environment or ease of counting. The goal of this research was to study correlation among stability parameters. In total of 16 stability parameters were used in this research. Saepo modi $\left(S M_{s p}\right)$ as a stability parameter was also used. Branch rust incidence, leaf rust incidence, and leaf rust severity on Arabica coffee were used as variables. This research result showed that none of the parameters of stability correlated significantly with all parameter of stability. It coud be concluded that if someone want to use only one stability parameter, it is preffered to make use of regression and deviation from regression $\left(D^{2}{ }_{i}\right)$. In the case a researcher needs to use several of parameters of stability, Saepo modi $\left(S_{s p}\right)$ might be exercised.
\end{abstract}

Keywords: genotypes, interaction, leaf rust, parameter

\begin{abstract}
ABSTRAK
Suatu fenotipe yang stabil yang diharapkan. Banyak metode statistik tersedia untuk mengukur stabilitas. Sejauh ini, pemilihan parameter stabilitas tergantung kepada persepsi tentang interaksi genotipe dengan lingkungan atau kemudahan perhitungan. Tujuan dari penelitian ini adalah untuk mengkaji korelasi antarparameter stabilitas. Sebanyak 16 parameter stabilitas digunakan pada penelitian ini. Saepo modi $\left(\mathrm{SM}_{\mathrm{sp}}\right)$ sebagai suatu parameter stabilitas juga digunakan. Insiden karat cabang, insiden karat daun dan keparahan karat daun pada kopi Arabica digunakan sebagai variabel. Hasil penelitian ini menunjukkan bahwa tidak satupun dari parameter stabilitas berkorelasi signifikan dengan semua parameter stabilitas. Kesimpulan penelitian ini adalah jika seseorang ingin menggunakan hanya satu parameter stabilitas, ia
\end{abstract}




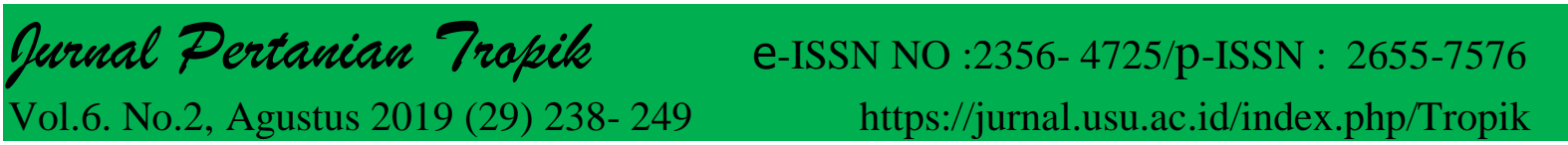

disarankan menggunakan regresi dan deviasi dari regresi $\left(\mathrm{D}^{2}{ }_{\mathrm{i}}\right)$. Dalam hal seorang peneliti ingin menggunakan beberapa parameter stabilitas, Saepo modi $\left(\mathrm{SM}_{\mathrm{sp}}\right)$ dapat digunakan.

Kata kunci: genotipe, interaksi, karat daun, parameter

\section{INTRODUCTION}

Task of plant breeding is to create the best genotype with high quantity, quality and stability of production over a wide range of growth environment. Experiments over seasons and years must be carried out to test the stability of genotypes perfing certain phenotypes because rank of genotypes could be changed in differen environment due to interaction of genotype and enviroment. Test of stability was used in the important commodities such as barley (Sabaghnia et al., 2012), black spure (Khalil, 1984), Chenopodium spp (Bhargava et al., 2005), chili pepper (Syukur etal., 2014), durum wheat (Akcura et al., 2006), faba bean (Temesgen et al., 2015), field pea (Fikere et al., 2010), lentil (Dehghani et al., 2008), maize (Scapim et al., 2000), oilseed rape (Brandle and McVetty, 1988; Oghan et al., 2013), potato (Flis et al., 2014), rice (Purbokurniawan et al., 2014, Balakrishnan et al., 2016), rubber tree (Silva et al., 2014), sorghum (Adugna, 2008), sugar cane (Rea et al., 2017), sweet potato (Bacusmo et al., 1988), and vetch (Sayar et al., 2013).

The concepts of stability comprises dynamic and static stability. Dynamic stability of phenotype describes the ability of a genotype to increase its performance in better growth environment as well as to decrease its performance in worse growth condition. Static phenotypic stability explains the ability of genotype to perform constantly in various growth environment.
These concepts cause different statistical methods which are variance analysis (Roemer, 1917), regression (Finlay and Wilkinson, 1963), and non-parametric (Lin and Binns, 1988). Number of statistical methods for measuring stability increased (Becker and Leon, 1988).

Researchers use one or several of them based on the assumptions about the nature of $\mathrm{G} \times \mathrm{E}$ interaction as well as the need for an easy statistical calculation. It is needed to study correlation among those stability parameters. The objectives of this research was to study correlation among parameter of statistical methods for measuring of phenotypic stability. It was hypothesized that there was significant correlations among parameter of stabilities. Result of this research was expected to contribute to better understanding of analysis of stability as well as to help choosing appropriate parameter of stability.

\section{MATERIAL AND METHOD}

General forms of the observed value of $\mathrm{k}$ genotypes in $\mathrm{n}$ environments is presented in Table $2 . \mathrm{X}_{\mathbf{i j}}$ is the observed value of the genotype $i^{\text {th }}$ at the environment $\mathrm{j}^{\text {th }} . \quad \overline{\mathrm{X}}_{\mathrm{i} . \text { is }}$ the average performance of the genotype $i^{\text {th }}$ at the environments $\mathrm{j}(\mathrm{j}=$ $1,2,3, \ldots . . \mathrm{n}) . \quad \bar{X}_{. j}$ is the mean value of environment $\mathrm{j}^{\text {th }}$ across the genotypes $\mathrm{i}(\mathrm{i}=$ $1,2,3, \ldots . . \mathrm{k}) . \overline{\mathrm{X}}_{\text {.. is }}$ the general mean of all genotypes across the environments. $\mathrm{X}$.. is the grand total of the observed values. 
Table 2. Hypothetical performance of $\mathrm{k}$ genotypes in $\mathrm{n}$ environments.

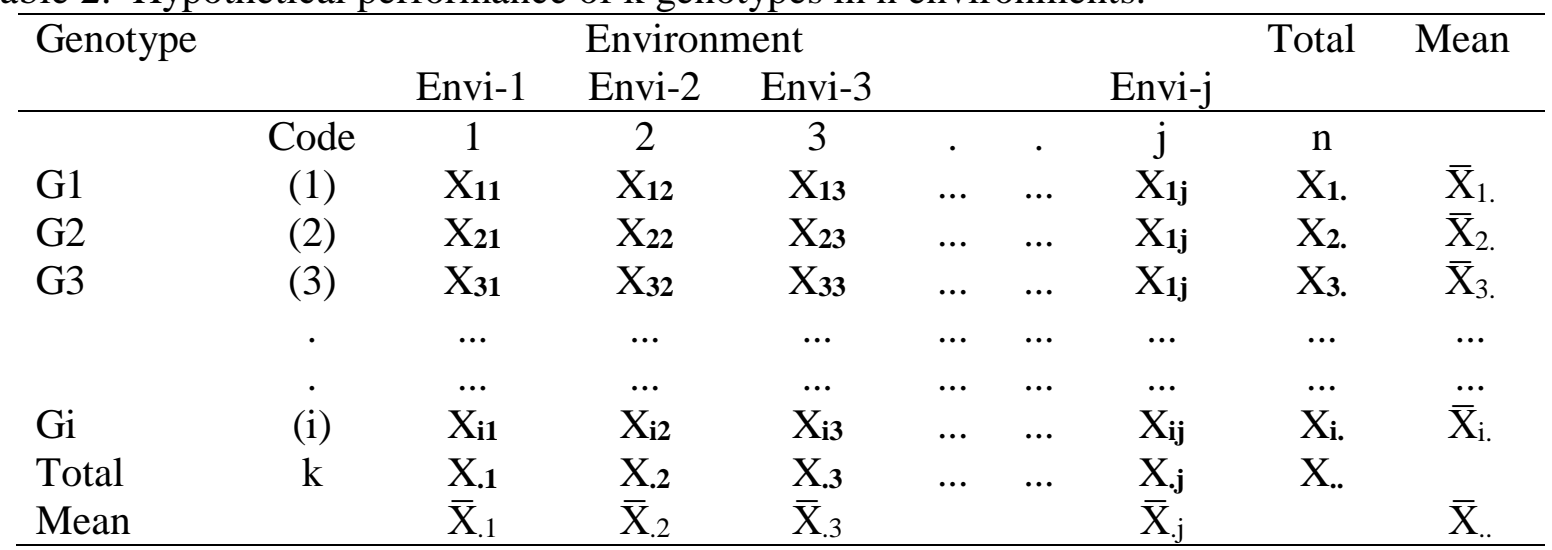

In this research, sixteen of the statistical methods for measuring the stability were used. They are based on the variance analysis (Roemer, 1917; Plaisted and Peterson, 1959; Plaisted, 1960; Wricke, 1962; Shukla, 1972; Francis and Kannenberg, 1978), regression (Finlay and Wilkinson, 1963; Eberhart and Russel, 1966; Perkins and Jinks, 1968; Hanson, 1970; Tai, 1971; Pinthus, 1973), and nonparametric (Lin and Binns, 1988; Kang, 1993).

Roemer (1917) proposed the deviation of the performance of the genotype from the genotypic mean $\left(\mathrm{x}_{\mathrm{ij}}-\overline{\mathrm{x}}_{\mathrm{i} .}\right)$ as the indication of the enviromental effect. The environmental variance of the genotype across the environments $\left(\mathrm{s}_{\mathrm{i}}^{2}\right)$ is the measurement of stability of genotype. The genotype that shows the smallest $\mathrm{s}_{\mathrm{i}}{ }^{2}$ is the most stable. The greatest stability is $\mathrm{si}^{2}$ close to 0 . The formula is

$$
s_{i}^{2}=\sum_{j=1}^{n} \frac{\left(x_{i j}-\bar{x}_{i .}\right)^{2}}{k-1} .
$$

Plaisted and Peterson (1959) suggested the mean variance component for pairwise $\mathrm{GxE}$ interaction $\left(\theta_{\mathrm{i}}\right)$ as stability measure. The genotype with smaller $\theta_{\mathrm{i}}$ is more stable. The formula is

$$
\begin{aligned}
& \theta_{\mathrm{i}}=\frac{\mathrm{k}}{2(\mathrm{k}-1)(\mathrm{n}-1)}+\sum_{\mathrm{j}=1}^{\mathrm{n}}\left[\left(\mathrm{x}_{\mathrm{ij}}-\right.\right. \\
& \left.\left.\overline{\mathrm{x}}_{\mathrm{i} .}\right)-\left(\overline{\mathrm{x}}_{\mathrm{j}}-\overline{\mathrm{x}}_{\mathrm{.}}\right)\right]^{2}+ \\
& \frac{\sum_{\mathrm{i}=1}^{\mathrm{k}} \sum_{\mathrm{j}=1}^{\mathrm{n}}\left[\left(\mathrm{x}_{\mathrm{ij}}-\overline{\mathrm{x}}_{\mathrm{i} .}\right)-\left(\overline{\mathrm{x}}_{\mathrm{j}}-\overline{\mathrm{x}}_{\mathrm{x}}\right)\right]^{2}}{2(\mathrm{k}-1)(\mathrm{n}-1)} .
\end{aligned}
$$

Plaisted (1960) proposed the GxE interaction variance from the subset $\left(\theta_{(i)}\right)$ as measurement of stability index of the genotype. The smaller the $\theta_{(i)}$ is, the more stable the genotype is. The formula is

$$
\begin{gathered}
\theta_{(i)}=\frac{-k}{(k-1)(k-2) /(n-1)}+ \\
\sum_{j=1}^{n}\left[\left(x_{i j}-\bar{x}_{i .}\right)-\left(\bar{x}_{. j}-\bar{x}_{. .}\right)\right]^{2}+ \\
\frac{\sum_{i=1}^{k} \sum_{j=1}^{n}\left[\left(x_{i j}-\bar{x}_{i .}\right)-\left(\bar{x}_{. j}-\bar{x}_{. .}\right)\right]^{2}}{(k-2)(n-1)} .
\end{gathered}
$$

Wricke (1962) offered the idea that the genotypes contribute to the $\mathrm{G} \times \mathrm{E}$ interaction. The deviation of the genotypic effect $\left(\mathrm{x}_{\mathrm{ij}}-\overline{\mathrm{x}}_{\mathrm{i}}\right)$ from the environmental effect $\left(\bar{x}_{. j}-\bar{x}_{. .}\right)$is the genotypic contribution to $\mathrm{G} \times \mathrm{E}$ interaction. The magnitude of this deviation is measured by the variance $\left(\mathrm{W}^{2}{ }_{\mathrm{i}}\right)$ termed ecovalence. The least $\mathrm{W}^{2}{ }_{i}$ (the highest ecovlaence) is the most stable. The greatest stability is $\mathrm{W}^{2}{ }_{\mathrm{i}}=0$. The formula is

$$
\begin{gathered}
\mathrm{W}_{\mathrm{i}}^{2}=\sum_{\mathrm{j}=1}^{\mathrm{n}}\left[\left(\mathrm{x}_{\mathrm{ij}}-\overline{\mathrm{x}}_{\mathrm{i} .}\right)-\left(\overline{\mathrm{x}}_{\mathrm{.j}}-\right.\right. \\
\left.\left.\overline{\mathrm{x}}_{. . .}\right)\right]^{2} .
\end{gathered}
$$

Shukla (1972) proposed stability variance $\left(\sigma^{2}\right)$ which is the partitioning of the $\mathrm{G} \times \mathrm{E}$ sum of square into component for each genotype separately. The smaller $\sigma^{2}{ }_{i}$ is, the more stable is. The most stable is genotype with $\sigma^{2}{ }_{i}=0$. Negative value of $\sigma^{2}{ }_{i}$ is equal to zero. The formula is 


$$
\begin{gathered}
\sigma_{\mathrm{i}}^{2}=\frac{\mathrm{k}}{(\mathrm{k}-2)(\mathrm{n}-1)}+\sum_{\mathrm{j}=1}^{\mathrm{n}}\left[\left(\mathrm{x}_{\mathrm{ij}}-\right.\right. \\
\left.\left.\overline{\mathrm{x}}_{\mathrm{i} .}\right)-\left(\overline{\mathrm{x}}_{\mathrm{j}}-\overline{\mathrm{x}}_{. .}\right)\right]^{2}+ \\
\frac{\sum_{\mathrm{i}=1}^{\mathrm{k}} \sum_{\mathrm{j}=1}^{\mathrm{n}}\left[\left(\mathrm{x}_{\mathrm{ij}}-\overline{\mathrm{x}}_{\mathrm{i} .}\right)-\left(\overline{\mathrm{x}}_{\mathrm{j}}-\overline{\mathrm{x}}_{\mathrm{.}}\right)\right]^{2}}{(\mathrm{k}-1)(\mathrm{k}-2)(\mathrm{n}-1)} .
\end{gathered}
$$

Francis and Kannenberg (1978) proposed relative variability as measument of stability. Relative variability is repesented by coefficient of variation (CV). Genotype with small $\mathrm{CV}$ is stable. $\mathrm{CV}$ close to 0 is the greatest stability. The formula is

$$
\mathrm{CV}_{\mathrm{i}}=\frac{\sqrt{\sum_{\mathrm{j}=1}^{\mathrm{n}} \frac{\left(\mathrm{x}_{\mathrm{ij}}-\overline{\mathrm{x}}_{\mathrm{i} .}\right)^{2}}{\mathrm{k}-1}}}{\overline{\mathrm{x}}_{\mathrm{i} .}} \times 100 \% .
$$

Finlay and Wilkinson (1963) proposed regression coefficient as measure of stability. The unity coefficient is $\left|b_{i}=-1\right|$. The genotype with $\mathrm{b}=1$ is the most stable. The formula is

$$
b_{i}=\frac{\sum_{j=1}^{n}\left(x_{i j}-\bar{x}_{i .}\right)\left(\bar{x}_{. j}-\bar{x}_{. .}\right)}{\sum_{j=1}^{n}\left(x_{. j}-\bar{x}_{. .}\right)^{2}} .
$$

Eberhart and Russel (1966) defined the measure of stability as residual mean square of deviation from the regression $\left(\delta^{2}{ }_{i}\right)$. The genotype with smaller $\delta^{2}{ }_{i}$ is more stable. The formula is

$$
\begin{aligned}
& \delta_{I}^{2}=\frac{1}{n-2}\left[\sum_{j=1}^{n}\left(\mathrm{x}_{\mathrm{ij}}-\overline{\mathrm{x}}_{\mathrm{i} .}\right)^{2}-\right. \\
& \left.\beta_{i}^{2} \sum_{\mathrm{j}=1}^{\mathrm{n}}\left(\mathrm{x}_{\mathrm{j}}-\overline{\mathrm{x}}_{. .}\right)^{2}\right] .
\end{aligned}
$$

Perkins and Jinks (1968) proposed the regression coefficient $\left(\beta_{\mathrm{i}}\right)$ and the deviation from the regression line of each environment $\left(\boldsymbol{\psi}^{2} \boldsymbol{i}\right)$ as the measure of stability. A genotype is considered stable if $\beta_{\mathrm{i}}=0$ and $\boldsymbol{\psi}^{2}{ }_{i}=0$. The formula are

$$
\begin{array}{r}
\beta_{i}=\frac{\sum_{\mathrm{j}=1}^{\mathrm{n}}\left[\left(\mathrm{x}_{\mathrm{ij}}-\overline{\mathrm{x}}_{\mathrm{i} .}\right)-\left(\overline{\mathrm{x}}_{\mathrm{j}}-\overline{\mathrm{x}}_{. .}\right)\right]\left(\mathrm{x}_{\mathrm{j}}-\overline{\mathrm{x}}_{. .}\right)}{\sum_{\mathrm{j}=1}^{\mathrm{n}}\left(\mathrm{x}_{\mathrm{j} . \mathrm{j}}-\overline{\mathrm{x}}_{. .}\right)^{2}} \\
\text { and } \\
\psi_{I}^{2}=\frac{1}{n-2}\left[\sum _ { \mathrm { j } = 1 } ^ { \mathrm { n } } \left[\left(\mathrm{x}_{\mathrm{ij}}-\overline{\mathrm{x}}_{\mathrm{i} .}\right)-\right.\right. \\
\left.\left.\left(\overline{\mathrm{x}}_{\mathrm{j} \mathrm{j}}-\overline{\mathrm{x}}_{. .}\right)\right]^{2}-\beta_{i}^{2} \sum_{\mathrm{j}=1}^{\mathrm{n}}\left(\mathrm{x}_{. \mathrm{j}}-\overline{\mathrm{x}}_{. .}\right)^{2}\right] .
\end{array}
$$

Hanson (1970) proposed regression and deviation from regression $\left(\mathrm{D}^{2}{ }_{\mathrm{i}}\right)$ as stability measurement. The magnitude of the deviation of the genotypic effect $\left(\mathrm{x}_{\mathrm{ij}}\right.$ $\left.\overline{\mathrm{x}}_{\mathrm{i} .}\right)$ from the environmental effect $\left(\overline{\mathrm{x}}_{\mathrm{j}}-\overline{\mathrm{x}}_{. .}\right)$ is calculated by using the minimum observed simple coefficient regression $b$ $\left(b_{m}\right)$. The stable gonotype does not deviate from the straight line. The genotype with smaller $\mathrm{D}^{2}{ }_{\mathrm{i}}$ is more stable. The formula is

$$
D_{i}^{2}=\sum_{j=1}^{n}\left[\left(\mathrm{x}_{\mathrm{ij}}-\overline{\mathrm{x}}_{\mathrm{i} .}\right)-b_{m}\left(\overline{\mathrm{x}}_{\mathrm{.j}}+\right.\right.
$$

Tai (1971) proposed the partitioning of GxE interaction into the linear response of genotype to the environmental effect $\left(\alpha_{\mathrm{i}}\right)$ and the deviation from the linear response $\left(\lambda_{i}\right)$ as measure of stability. The stability of genotype is characterize by $\alpha_{\mathrm{i}}$ and $\lambda_{\mathrm{i}}$. The genotype with $\left(\alpha_{i}=-1, \lambda_{i}=1\right)$ is the most stable, while the genotype with $\left(\alpha_{\mathrm{i}}=0, \lambda_{\mathrm{i}}=\right.$ 1) has an average stability across environment. The gonotype with $\left(\alpha_{\mathrm{i}}, \lambda_{\mathrm{i}}\right)<$ $(0,1)$ performs an above-average stability, and genotype with $\left(\alpha_{\mathrm{i}}, \lambda_{\mathrm{i}}\right)>(0,1)$ shows a below-average stability. The formula are

$$
\begin{aligned}
& \alpha_{i}= \\
& \frac{\left\{\sum_{j=1}^{n}\left(\overline{\mathrm{x}}_{\mathrm{j}}-\overline{\mathrm{x}}_{. .}\right)\left[\left(\mathrm{x}_{\mathrm{ij}}-\overline{\mathrm{x}}_{\mathrm{i} .}\right)-\left(\overline{\mathrm{x}}_{\mathrm{j}}-\overline{\mathrm{x}}_{. .}\right)\right]\right\} /(n-1)}{\left(M S_{E n v}-M S_{R e p(E n v)}\right) /(k r)} \text {, and } \\
& \lambda_{i}=
\end{aligned}
$$

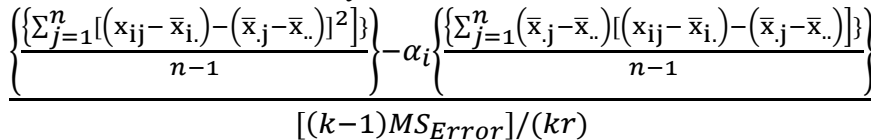

whereby MS mean square, $\mathrm{MS}_{\mathrm{Env}}=\mathrm{MS}$ of environment (location), $\mathrm{MS}_{\mathrm{Rep}(\mathrm{Env})}=\mathrm{MS}$ of replication within environment, $\mathrm{k}=$ number of genotype, $\mathrm{n}=$ number of environment, $\mathrm{MS}_{\text {Error }}=\mathrm{MS}$ of error $(\mathrm{MS}$ of pooled error), and $r=$ number of replication.

Pinthus (1973) proposed the amount of the variation in genotypes that can be explained by the variation of environment i.e coefficient of determination $\left(\mathrm{r}^{2}\right)$ as stability measure. The coefficient of determination is calculated as the proportion of variation in genotypes from the total variation. The value of $\mathrm{r}^{2}$ ranks is $0(0 \%)$ to $1(100 \%)$. The genotype with $r^{2}=1$ is the most stable. The formula is

$$
r^{2}=\left\{\frac{\sum_{\mathrm{j}=1}^{\mathrm{n}}\left(\mathrm{x}_{\mathrm{ij}}-\overline{\mathrm{x}}_{\mathrm{i}}\right)\left(\overline{\mathrm{x}}_{\mathrm{j}}-\overline{\mathrm{x}}_{. .}\right)}{\sum_{\mathrm{j}=1}^{\mathrm{n}}\left(\mathrm{x}_{\mathrm{j} . \mathrm{j}}-\overline{\mathrm{x}}_{. .}\right)^{2}}\right\}^{2}
$$


Lin and Binns (1988) proposed the superiority of genotype over a series of environments (n) as measure of stability. The superiority of the genotype is the distance of the genotype performance from the maximal performance for that environment $\left(\mathrm{x}_{\mathrm{ij}}-\mathrm{Max}_{\mathrm{j}}\right)$. The genotype with smaller variance of the superiority of the genotype averaged over all environments $\left(\mathrm{P}_{\mathrm{i}}\right)$ is more stable. The formula is

$$
P_{i}=\sum_{j=1}^{n} \frac{\left(x_{i j}-M a x_{j}\right)^{2}}{2 n} .
$$

Kang (1993) proposed the sum of rank $\left(\kappa_{\mathrm{i}}\right)$ of the observed performance of the genotype $\left(\mathrm{R}_{\mathrm{ig}}\right)$ with rank of of the genotype based on Sukla's stability variance $\left(\mathrm{R}_{\mathrm{is}}\right)$ as measure of stability. Based on the genotype performance, the genotype with the highest performance is number 1. Based on the Sukla's stability variance, the genotype with the smallest Sukla's stability get number 1 . The genotype with smaller $\kappa_{\mathrm{i}}$ is more stable. The formula is

$$
\kappa_{i}=R_{i g}+R_{i s} .
$$

The authors of this paper propose the frequency as the basis for analysis which is termed saepe modi (Latin) abbreviated as SM. The best parameter of stability is the one that has the highest number of significant correlations $\left(\mathrm{SM}_{\mathrm{sp}}\right)$ with other parameters. This method might be a nonparametric method.

Data of branch rust incidence, leaf rust incidence, and leaf rust severity on coffee leaves from coffee a field xperiment were used.

\section{RESULT AND DISCUSSION}

Analysis of stability parameters showed that none of the stability parameters were significantly correlated with all stability parameters in each phenotype (Table 1). Stability parameter $\mathrm{D}^{2}{ }_{\mathrm{i}}$ of Hanson (1970) for branch rust incidence correlated most frequently $\left(\mathrm{SM}_{\mathrm{sp}}=11\right)$ with other parameters of stability. However, stability parameter $\psi^{2}{ }_{i}$ of Perkins and Jinks (1968) and $\mathrm{CV}_{\mathrm{i}}$ of Francis and Kannenberg (1978) for leaf rust incidence had the highest frequency $\left(\mathrm{SM}_{\mathrm{sp}}=11\right)$. Stability parameter $\mathrm{s}^{2}{ }_{\mathrm{i}}$ of Roemer (1917), $\delta^{2}{ }_{\mathrm{i}}$ of Eberhart and Russel (1966), $\mathrm{D}^{2}$ i of Hanson (1970), and $r^{2}{ }_{i}$ of Pinthus (1973) for leaf rust severity performed the same highest frequency $\left(\mathrm{SM}_{\mathrm{sp}}=13\right)$. The research result also showed that number of the frequency of the significant correlation among stability parameters were different if phenotypes were different (Table 1). The numbers ranged from 2 to 11,4 to 11 and 1 to13 for branch rust incidence, leaf rust incidence and leaf rust severity, respectively. Out of the total number of correlation over three phenotypes of each stability parameter (45), $\mathrm{D}^{2}{ }_{\mathrm{i}}$ of Hanson (1970) had the highest number of the significant correlations $\left(\mathrm{SM}_{\mathrm{sp}}=33\right)$.

These research results implicated that none of the stability parameters could represent all stability parameters. Based on that, several stability parameters should be used to obtain a strong basis for choosing the most stable phenotype or the most stable genotypes in a certain phenotype. In the case of selecting one parameter of stability, however, $\mathrm{D}^{2}{ }_{\mathrm{i}}$ of Hanson (1970) could be considered to be chosen. This suggestion was in contrary with research result of Temesgen et al. (2015). Choosing $\mathrm{D}^{2}{ }_{\mathrm{i}}$ of Hanson (1970) as parameter of stability based on the saepe modi (Table 1, $\mathrm{SM}_{\mathrm{sp}}=33$ ) was entirely different with other selecting methods based which wa based on the prediction of the nature of $G \times E$ interaction and the need of a simple statistical method (Freeman, 1973; Becker, 1981; Lin et al., 1986; St.Clair and Kleinschmit, 1986; Becker and Leon, 1988; Bacusmo et al., 1988; Magari and Kang, 1993; Piepho, 1994; Ferreira et al., 2006; Souza et al., 2007; Mitrovic et al., 2011; Nascimento et al., 2013; Syukur etal., 2014; Balakrishnan et al., 2016). 
Table 1. Correlation among parameters of stability in branch rust incidence, leaf rust incidence, and leaf rust severity

\begin{tabular}{|c|c|c|c|c|c|c|c|c|c|c|c|c|c|c|c|c|c|c|}
\hline \multirow{3}{*}{$\begin{array}{l}\text { Para } \\
\text { met } \\
\text { er }\end{array}$} & \multirow[b]{3}{*}{$\begin{array}{l}\text { Vari } \\
\text { able }\end{array}$} & \multicolumn{6}{|c|}{ Variance } & \multicolumn{8}{|c|}{ Regression } & \multicolumn{3}{|c|}{ Nonparametric } \\
\hline & & \multicolumn{6}{|c|}{ Author and parameter } & \multicolumn{8}{|c|}{ Author and parameter } & \multicolumn{3}{|c|}{ Author and parameter } \\
\hline & & $\begin{array}{c}\text { Roeme } \\
r \\
(1917)\end{array}$ & $\begin{array}{c}\text { Plaiste } \\
d \text { and } \\
\text { Peters } \\
\text { on } \\
(1959) \\
\end{array}$ & $\begin{array}{c}\text { Plaiste } \\
d \\
(1960)\end{array}$ & $\begin{array}{l}\text { Wricke } \\
(1962)\end{array}$ & $\begin{array}{l}\text { Shukla } \\
(1972)\end{array}$ & $\begin{array}{c}\text { Francis } \\
\text { and } \\
\text { Kanne } \\
\text { nberg } \\
(1978) \\
\end{array}$ & $\begin{array}{c}\text { Finlay } \\
\text { and } \\
\text { Wilkins } \\
\text { on } \\
(1963) \\
\end{array}$ & $\begin{array}{c}\text { Eberha } \\
\text { rt and } \\
\text { Russel } \\
(1966)\end{array}$ & $\begin{array}{c}\text { Perkin } \\
\text { s and } \\
\text { Jinks } \\
(1968)\end{array}$ & $\begin{array}{c}\text { Perkins } \\
\text { and } \\
\text { Jinks } \\
(1968)\end{array}$ & $\begin{array}{c}\text { Hanso } \\
n \\
(1970)\end{array}$ & $\begin{array}{c}\text { Tai } \\
(1971)\end{array}$ & $\begin{array}{c}\text { Tai } \\
(1971\end{array}$ & $\begin{array}{c}\text { Pinthus } \\
\text { (1973) }\end{array}$ & $\begin{array}{c}\text { Linn } \\
\text { and } \\
\text { Binns } \\
(1978)\end{array}$ & $\begin{array}{c}\text { Kang } \\
(1993)\end{array}$ & \\
\hline & & $s^{2}$ & $\theta_{\mathrm{i}}$ & $\theta_{(i)}$ & $W^{2} i_{i}$ & $\sigma^{2} i$ & $\mathrm{CV}_{\mathrm{i}}$ & $b_{i}$ & $\delta^{2}$ & $\beta_{i}$ & $\psi^{2}{ }_{i}$ & $D i^{2}$ & $a_{i}$ & $\lambda_{\mathrm{i}}$ & $r_{i}^{2}$ & $\mathrm{P}_{\mathrm{i}}$ & $\kappa \mathrm{i}$ & $\mathrm{SM}_{\mathrm{sp}}$ \\
\hline $\mathrm{Si}^{2}$ & BRI & 1 & 0.541 & -0.541 & 0.541 & 0.541 & 0.593 & $\underset{* *}{0.988}$ & 0.999 & $\begin{array}{r}0.987 \\
* *\end{array}$ & 0.259 & $\begin{array}{r}0.765 \\
*\end{array}$ & 0.988 & 0.408 & -0.261 & 0.156 & 0.484 & 5 \\
\hline & & & ns & & ns & ns & & $* *$ & ** & ** & ** & ns & ** & ns & ns & ns & ns & \\
\hline & LRS & 1 & $\begin{array}{r}0.886 \\
* *\end{array}$ & $\begin{array}{r}-0.887 \\
\text { ** }\end{array}$ & $\begin{array}{r}0.886 \\
* *\end{array}$ & $\begin{array}{r}0.886 \\
* *\end{array}$ & $\begin{array}{r}0.987 \\
* *\end{array}$ & $\underset{* *}{0.902}$ & $\underset{* *}{0.997}$ & $\underset{* *}{0.902}$ & $\underset{* *}{0.905}$ & $\begin{array}{r}0.979 \\
* *\end{array}$ & $\underset{* *}{0.902}$ & $\underset{* *}{0.903}$ & $\begin{array}{r}0.979 \\
* *\end{array}$ & $\begin{array}{r}0.097 \\
\text { ns }\end{array}$ & $\begin{array}{r}0.610 \\
n s\end{array}$ & 13 \\
\hline$\theta_{\mathrm{i}}$ & BRI & & 1 & $\begin{array}{r}-1.000 \\
* *\end{array}$ & $\begin{array}{r}1.000 \\
* *\end{array}$ & $\begin{array}{r}1.000 \\
* *\end{array}$ & $\begin{array}{r}0.490 \\
\mathrm{~ns}\end{array}$ & $\begin{array}{r}0.402 \\
\mathrm{~ns}\end{array}$ & $\begin{array}{r}0.546 \\
\mathrm{~ns}\end{array}$ & $\begin{array}{r}0.400 \\
\mathrm{~ns}\end{array}$ & $\begin{array}{r}0.870 \\
*\end{array}$ & $\begin{array}{r}0.956 \\
* *\end{array}$ & $\begin{array}{r}0.403 \\
\mathrm{~ns}\end{array}$ & $\begin{array}{r}0.965 \\
* *\end{array}$ & $\begin{array}{r}-0.925 \\
* *\end{array}$ & $\begin{array}{r}0.391 \\
\text { Ns }\end{array}$ & $\begin{array}{r}0.782 \\
\text { * }\end{array}$ & 8 \\
\hline & LRI & & 1 & -1.000 & $\begin{array}{r}1.000 \\
* *\end{array}$ & $\begin{array}{r}1.000 \\
* *\end{array}$ & $\begin{array}{r}0.848 \\
\text { * }\end{array}$ & $\begin{array}{r}0.162 \\
n s\end{array}$ & $\begin{array}{r}0.495 \\
\mathrm{~ns}\end{array}$ & $\begin{array}{r}0.160 \\
\mathrm{~ns}\end{array}$ & $\begin{array}{r}0.993 \\
* *\end{array}$ & $\underset{* *}{0.963}$ & $\begin{array}{r}0.158 \\
\mathrm{~ns}\end{array}$ & $\underset{* *}{0.997}$ & $\begin{array}{r}-0.993 \\
\text { * }\end{array}$ & $\underset{* *}{0.887}$ & $\begin{array}{r}0.811 \\
\text { * }\end{array}$ & 10 \\
\hline & LRS & & 1 & $\begin{array}{r}-1.000 \\
* *\end{array}$ & $\begin{array}{r}1.000 \\
* *\end{array}$ & $\begin{array}{r}1.000 \\
* *\end{array}$ & $\begin{array}{r}0.898 \\
* *\end{array}$ & $\begin{array}{r}0.600 \\
\mathrm{~ns}\end{array}$ & $\begin{array}{r}0.866 \\
\text { * }\end{array}$ & $\begin{array}{r}0.600 \\
\mathrm{~ns}\end{array}$ & $\begin{array}{r}0.965 \\
* *\end{array}$ & $\begin{array}{r}0.963 \\
* *\end{array}$ & $\begin{array}{r}0.600 \\
\mathrm{~ns}\end{array}$ & -0.992 & $\underset{* *}{0.963}$ & $\begin{array}{r}0.377 \\
\mathrm{~ns}\end{array}$ & $\begin{array}{r}0.702 \\
\mathrm{~ns}\end{array}$ & 10 \\
\hline & LRI & & & 1 & $\begin{array}{r}-1.000 \\
* *\end{array}$ & $\begin{array}{r}-1.000 \\
* *\end{array}$ & $\begin{array}{r}-0.848 \\
\text { * }\end{array}$ & $\begin{array}{r}-0.162 \\
n s\end{array}$ & $\begin{array}{r}-0.495 \\
n s\end{array}$ & $\begin{array}{r}-0.160 \\
n s\end{array}$ & $\begin{array}{r}-0.993 \\
* *\end{array}$ & $\begin{array}{r}-0.963 \\
* *\end{array}$ & $\begin{array}{r}-0.158 \\
n s\end{array}$ & $\begin{array}{r}-0.997 \\
* *\end{array}$ & $\begin{array}{r}0.993 \\
\text { * }\end{array}$ & $\begin{array}{r}-0.887 \\
* *\end{array}$ & $\begin{array}{r}-0.811 \\
\text { * }\end{array}$ & 10 \\
\hline & LRS & & & 1 & $\begin{array}{r}-1.000 \\
* *\end{array}$ & $\begin{array}{r}-1.000 \\
* *\end{array}$ & $\begin{array}{r}-0.898 \\
* *\end{array}$ & $\begin{array}{r}-0.600 \\
n s\end{array}$ & $\begin{array}{r}-0.866 \\
\text { * }\end{array}$ & $\begin{array}{r}-0.600 \\
n s\end{array}$ & $\begin{array}{r}-0.965 \\
* *\end{array}$ & $\begin{array}{r}-0.963 \\
* *\end{array}$ & $\begin{array}{r}-0.600 \\
n s\end{array}$ & $\begin{array}{r}0.992 \\
* *\end{array}$ & $\begin{array}{r}-0.963 \\
* *\end{array}$ & $\begin{array}{r}-0.377 \\
\mathrm{~ns}\end{array}$ & $\begin{array}{r}-0.701 \\
n s\end{array}$ & 10 \\
\hline $\mathrm{W}^{2}$ & BRI & & & & 1 & $\begin{array}{r}1.000 \\
* *\end{array}$ & $\begin{array}{r}0.490 \\
\mathrm{~ns}\end{array}$ & $\begin{array}{r}0.402 \\
\mathrm{~ns}\end{array}$ & $\begin{array}{r}0.546 \\
\mathrm{~ns}\end{array}$ & $\begin{array}{r}0.400 \\
\mathrm{~ns}\end{array}$ & $\begin{array}{r}0.870 \\
\text { * }\end{array}$ & $\underset{* *}{0.956}$ & $\begin{array}{r}0.403 \\
\mathrm{~ns}\end{array}$ & $\underset{* *}{0.965}$ & $\underset{* *}{-0.925}$ & $\begin{array}{r}0.391 \\
n s\end{array}$ & $\begin{array}{r}0.782 \\
*\end{array}$ & 8 \\
\hline & LRI & & & & 1 & 1.000 & $\begin{array}{r}0.848 \\
\text { * }\end{array}$ & $\begin{array}{r}0.162 \\
n s\end{array}$ & $\begin{array}{r}0.495 \\
\mathrm{~ns}\end{array}$ & $\begin{array}{r}0.160 \\
n s\end{array}$ & $\underset{* *}{0.993}$ & $\begin{array}{r}0.963 \\
* *\end{array}$ & $\begin{array}{r}0.158 \\
n s\end{array}$ & 0.997 & $\begin{array}{r}-0.993 \\
\text { * }\end{array}$ & $\begin{array}{r}0.887 \\
* *\end{array}$ & $\begin{array}{r}0.811 \\
\text { * }\end{array}$ & 10 \\
\hline & LRS & & & & 1 & $\begin{array}{r}1.000 \\
* *\end{array}$ & $\begin{array}{r}0.898 \\
* *\end{array}$ & $\begin{array}{r}0.600 \\
\mathrm{~ns}\end{array}$ & $\begin{array}{r}0.866 \\
\text { * }\end{array}$ & $\begin{array}{r}0.600 \\
n s\end{array}$ & $\underset{* *}{0.965}$ & $\begin{array}{r}0.963 \\
* *\end{array}$ & $\begin{array}{r}0.600 \\
\mathrm{~ns}\end{array}$ & $\underset{* *}{0.992}$ & $\begin{array}{r}0.963 \\
* *\end{array}$ & $\begin{array}{r}0.377 \\
\text { ns }\end{array}$ & $\begin{array}{r}0.702 \\
\mathrm{~ns}\end{array}$ & 10 \\
\hline$\sigma^{2}$ & BRI & & & & & 1 & $\begin{array}{r}0.490 \\
\mathrm{~ns}\end{array}$ & $\begin{array}{r}0.402 \\
\mathrm{~ns}\end{array}$ & $\begin{array}{r}0.546 \\
\mathrm{~ns}\end{array}$ & $\begin{array}{r}0.400 \\
\mathrm{~ns}\end{array}$ & $\begin{array}{r}0.870 \\
\text { * }\end{array}$ & $\underset{* *}{0.956}$ & $\begin{array}{r}0.403 \\
\text { ns }\end{array}$ & $\begin{array}{r}0.965 \\
* *\end{array}$ & -0.925 & $\begin{array}{r}0.391 \\
\mathrm{~ns}\end{array}$ & $\begin{array}{r}0.782 \\
\text { * }\end{array}$ & 8 \\
\hline & LRI & & & & & 1 & $\begin{array}{r}0.848 \\
\text { * }\end{array}$ & $\begin{array}{r}0.162 \\
n s\end{array}$ & $\begin{array}{r}0.495 \\
\mathrm{~ns}\end{array}$ & $\begin{array}{r}0.160 \\
n s\end{array}$ & $\begin{array}{r}0.993 \\
* *\end{array}$ & $\begin{array}{r}0.963 \\
* *\end{array}$ & $\begin{array}{r}0.158 \\
\mathrm{~ns}\end{array}$ & $\underset{* *}{0.997}$ & $\begin{array}{r}-0.993 \\
* *\end{array}$ & $\underset{* *}{0.887}$ & $\begin{array}{r}0.811 \\
\text { * }\end{array}$ & 10 \\
\hline & LRS & & & & & 1 & $\begin{array}{r}0.898 \\
* *\end{array}$ & $\begin{array}{r}0.600 \\
\mathrm{~ns}\end{array}$ & $\begin{array}{r}0.866 \\
*\end{array}$ & $\begin{array}{r}0.600 \\
\text { ns }\end{array}$ & $\begin{array}{r}0.965 \\
* *\end{array}$ & $\begin{array}{r}0.963 \\
* *\end{array}$ & $\begin{array}{r}0.600 \\
n s\end{array}$ & $\underset{* *}{0.992}$ & $\begin{array}{r}0.963 \\
* *\end{array}$ & $\begin{array}{r}0.377 \\
\text { ns }\end{array}$ & $\begin{array}{r}0.702 \\
\mathrm{~ns}\end{array}$ & 10 \\
\hline
\end{tabular}




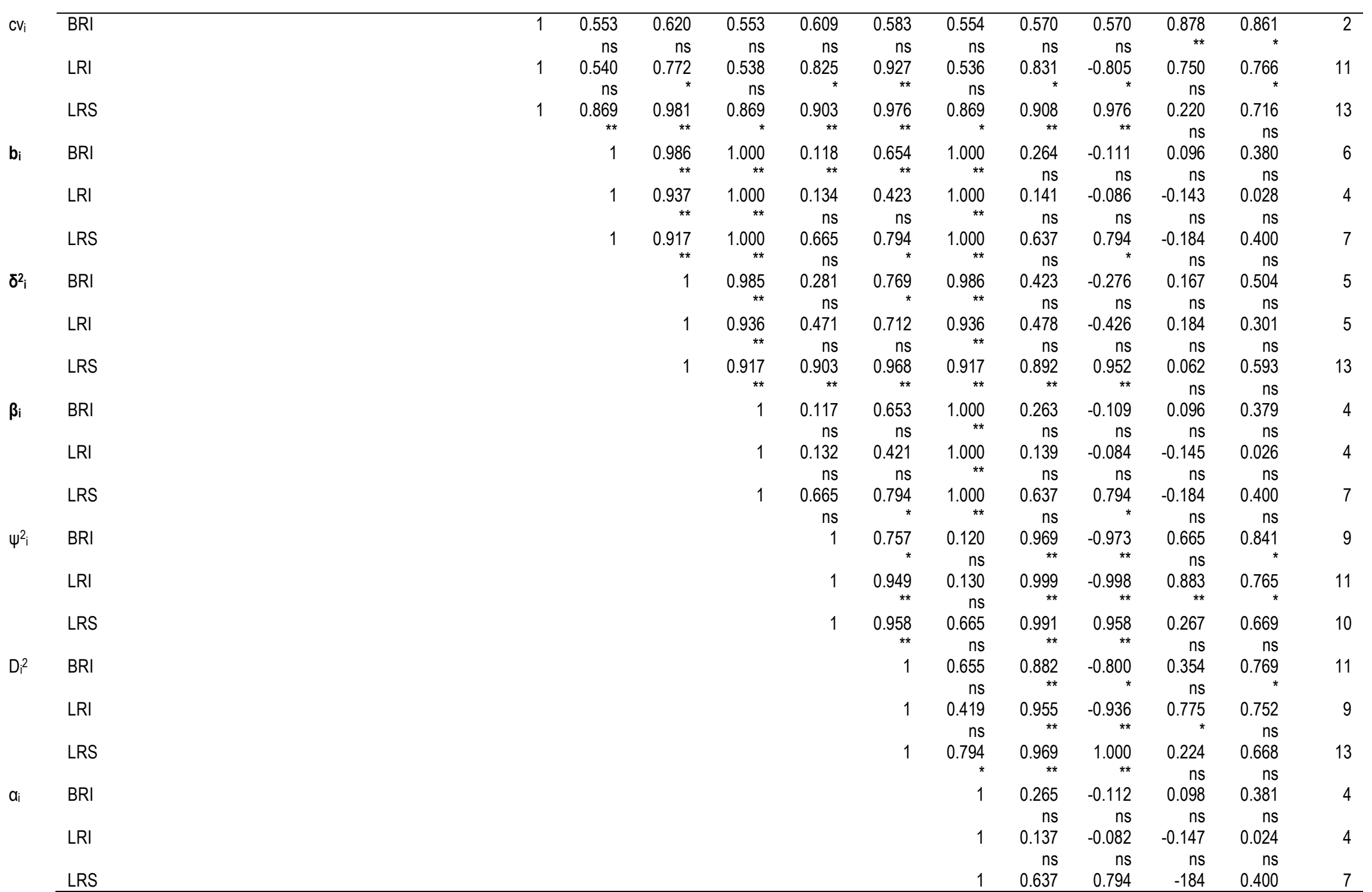




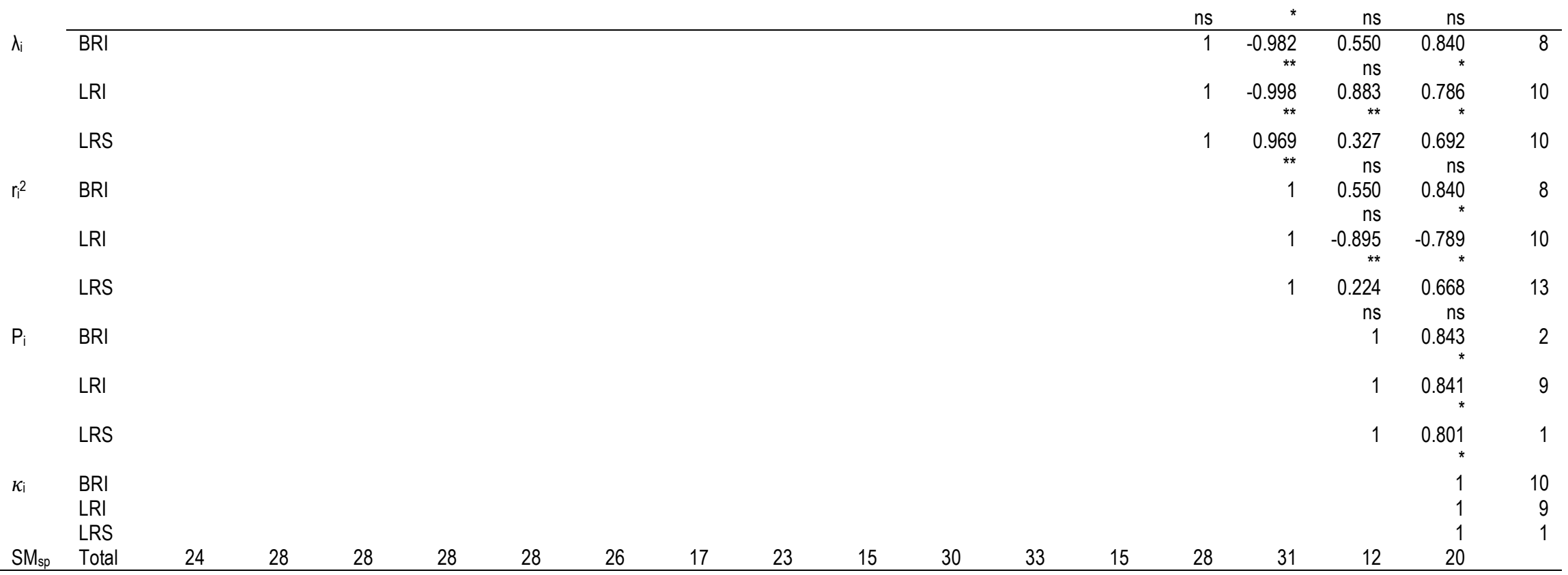

$\mathrm{n}=28, \mathrm{BRI}=$ branch rust incidence, $\mathrm{LRI}=$ leaf rust incidence, $\mathrm{LRS}=$ leaf rust severity, $\mathrm{ns}=$ not significant, $*=$ significant at $\alpha 0.05$ $=0.374$, and $* *=$ highly significant at $\alpha 0.01=0.478, \mathrm{SM}_{\mathrm{sp}}=$ number of frequency of parameter correlating significantly with others. 


\section{CONCLUSION}

This result proved that none of the parameters of stability could represent all stability all parameters. If someone prefer to use one parameter of stability, it is suggested to use regression and deviation from regression $\left(\mathrm{D}^{2} \mathrm{i}\right)$ proposed by Hanson (1970). However, if a researcher needs to use many stability parameters, Saepo modi $\left(\mathrm{SM}_{\mathrm{sp}}\right)$ could be considered to be used.

\section{ACKNOWLEDGEMENT}

The authors thank the Ministry of Research, Technology and Higher Education for funding this research with grant number 0100/E5.1/PE/2015 dated January 19, 2015.

\section{REFERENCES}

Adugna, A., 2008. Assessment of yield stability in sorghum using univariate and multivariate statistical approaches. Hereditas 145(1):28-37.

DOI: $10.1111 / \mathrm{j} .0018$ -

0661.2008.2023.X

Akcura, M., Kaya, Y., Taner, S., Ayranci, R., 2006. Parametric stability analyses for grain yield of durum wheat. Plant Soil Environ., 52(6): 254-261. DOI: $10.17221 / 3438$ PSE.

Bacusmo, J.L., Collins, W.W., Jones, A., 1988. Comparison of methods of determining stability and adaptation of sweet potato. Theoretical and Applied Genetics 75(3):492-497.

DOI: $10.1007 / \mathrm{BF} 00276755$.

Balakrishnan, D., Subrahmanyam,D., Badri, J., Raju, A.K., Rao, Y.V., Beerelli, K., Mesapogu, S., Surapaneni, M., Ponnuswamy, R., Padmawathi, G., Babu, V.R., Neelamraju, S., 2016. Genotype $\times$
Environment Interactions of Yield Traits in Backcross Introgression Lines Derived from Oryza sativa cv. Swarna/Oryza nivara. Frontiers in Plant Science 7,1-19. DOI: 10.3389/fpls.2016.01530.

Becker, H.C., 1981. Correlations among some statistical measures of phenotypic stability. Euphytica 30(3):835-840.

DOI: $10.1007 / \mathrm{BF} 00038812$.

Becker, H.C., Leon, 1988. Stabilty analysiss in plant breeding. Plant Breeding 101, 1-23. https://doi.org/10.1111/j.14390523.1988.tb00261.x

Bhargava, A., Shukla, S., Ohri, D., 2005. Analysis of Genotype $\times$ Environment Interaction for Grain Yield in Chenopodium spp. Czech Journal of Genetics and Plant Breeding 41(2), 64-72. DOI: $10.17221 / 3673-C J G P B$.

Brandle, J.E., McVetty, P.B.E., 1988. Genotype X environment interaction and stability analysis of seed yield of oilseed rape grown in Manitoba. Canadian Journal of Plant Science 68(2):381-388. DOI: $10.4141 /$ cjps88-049.

Dehghani, H., Sabaghpour, S.H., Sabaghnia, N., 2008. Genotype $\times$ environment interaction for grain yield of some lentil genotypes and relationship among univariate stability statistics. Spanish Journal Of Agricultural Research 6(3), 385-394.

DOI: $10.5424 / \mathrm{sjar} / 2008063-5292$.

Eberhart, S.A., Russel, W.A., 1966. Stability Parameters for Comparing Parameters. Crop Science, 6, 3640. http://dx.doi.org/10.2135/crops ci1966.0011183X000600010011x.

Ferreira, D.F., Demetrio, C.G.B., Manly, B.F.J., Machado, A.A., Vencovsky, R., 2006. Statistical model in agriculture: biometrical methods 
for evaluating phenotypic stability in plant breeding. Cerne Lavras 12(4), 373-388.

Fikere,M., Tadesse, T., Gebeyehu, S., Hundie, B., 2010. Agronomic performances, disease reaction and yield stability of field pea genotypes in Bale highlands, Ethiopia. Australian Journal of Crop Science 4(4):238-246.

Finlay, K.W., Wilkinson, G.N., 1963. The Analysis of Adaptation in a PlantBreeding Programme. Australian Journal of Agricultural Research, $14,742-$

754. http://dx.doi.org/10.1071/AR9 630742.

Flis, B., Domanski, L., ZimmochGuzowska, E., Polgar, Z., Pousa, S.A., Pawlak, A., 2014. Stability Analysis of Agronomic Traits in Potato Cultivars of Different Origin. American Journal of Potato Research 91(4):404-413. DOI: 10.1007/s12230-013-9364-6.

Francis, T.R., Kannenberg, L.W., 1978. Yield stability studies in shortseason maize. 1. A descriptive method for grouping genotypes. Can. J. Plant Sci. 58:1029-1034.

Freeman, G.H., 1973. Statistical Methods for the Analysis of GenotypeEnvironment Interactions. Heredity 31, 339-354.

Hanson, W.D., 1970. Genotypic stability. Theoretical and Applied Genetics 40(5):226-31. DOI: $10.1007 / \mathrm{BF} 00285245$.

Kang, M.S., 1993. Simultaneous Selection for Yield and Stability in Crop Performance Trials: Consequences for Growers. Agronomy Journal $85,754-$

757. https://doi.org/10.2134/agronj 1993.00021962008500030042x.

Khalil, M.A.K., 1984. All-range black spure provenance study in new foundland : performance and genotypic stability of provenance. Silvae Genetica 33, 63-71.

Lin, C.S., Binns, M.R., Lefkovitch, L.P., 1986. Stability Analysis : Where Do We Stand ? Crop Science 26, $894-900$.

Lin, C.S., Binns, M.R., 1988. A method of analyzing cultivar $\mathrm{x}$ location $\mathrm{x}$ year experiments: a new stability parameter. Theoretical and Applied Genetics 76(3):425-430. DOI: $10.1007 / \mathrm{BF} 00265344$.

Magari, R., Kang, M.S., 1993. Genotype selection via a new yield-stability statistic in maize yield trials. Euphytica 70(1):105-111. DOI: $10.1007 / \mathrm{BF} 00029647$.

Mitrovic, B., Stanisavljevi, D., Treski, S., Stojavonic, M., Ivanovic, M., Bekavac, G., Rajkovic, M., 2011. Evaluation of Experimental Maize Hybrids Tested in Multi-Location Trials Using Ammi and GGE Biplot Analyses. Turkish Journal of Field Crops 17(1):35-40.

Nascimento, M., Peternelli, L.A., Cruz, C.D., Nascimento, A.C.C., Ferreira, R.D.P., Bhering, L.L., Salgado, C.C., 2013. Artificial neural networks for adaptability and stability evaluation in alfalfa genotypes. Crop Breed. Appl. Biotechnol. 13, 152-156.

DOI: $10.1590 / \mathrm{S} 1984-$ 70332013000200008.

Oghan,H.A., Sabaghnia,N., Rameeh, V., Fanaee, H.R., Hezarjeribi, E., 2013. Univariate Stability Analysis of GenotypexEnvironment Interaction of Oilseed Rape Seed Yield. Acta Universitatis Agriculturae et Silviculturae Mendelianae Brunensis 64(5):1625-1634. DOI: 10.11118/actaun2016640516 25.

Perkins, J.M., Jinks, J.L., 1968. Environmental and genotype-environmental components of variability. III. 
Multiple lines and crosses.Heredity, 23(3), 339-356.

Piepho, H.P., 1994. A Comparison of the Ecovalence and the Variance of Relative Yield as Measures of Stability. J. Agronomy \& Crop Science 173, 1-4. https://doi.org/10.1111/j.1439037X.1994.tb00566.x.

Pinthus, M.J., 1973. Estimate of genotypic value: A proposed method. Euphytica 22: 121-123. https://doi.org/10.1007/BF000215 63

Plaisted, R.L., 1960. A shorter method for evaluating the ability of selections to yield consistently over locations. American Potato Journal 37(5):166-172.

Plaisted, R.L., Peterson, L.C., 1959. A technique for evaluating the stability of selections to yield consistently in different locations or seasons. American Potato Journal 36(11): 381-385.

Purbokurniawan, Purwoko, B.S., Wiras, D., Dewi, I.S., 2014. Yield potential and stability, and adaptability of new plant type of upland rice lines developed through anther culture. J. Agron. Indonesia 42 (1) : $9-16$. http://dx.doi.org/10.24831/jai.v42i1 .8142 .

Rea, R.A., Sousa-Vieira, O.D., Lucena, A.D., Ramón, M., Cárdenas, R.B., 2017. Genotype by environment interaction and yield stability in sugarcane. Revista Facultad Nacional de Agronomía Medellín 70(2):8129-8138.

DOI: 10.15446/rfna.v70n2.61790.

Roemer, J., 1917. Sind die ertragreichen Sorten ertragssicherer? Mitteilungen der DLG 32: 87-89.

Sabaghnia, N., Mohammadi, M., Karimizadeh, R., 2012. Yield stability of performance in multienvironment trials of barley
(Hordeum vulgare L.) genotypes. Acta Univ. Agric. Silvic. Mendelianae Brun. 2013, 61, 787793.

https://doi.org/10.11118/actaun201 361030787.

Sayar, M.S., Anlarsal, A.E., Basbag, M., 2013. Genotype-Environment Interactions and Stability Analysis for Dry-Matter Yield and Seed Yield in Hungarian Vetch (Vicia pannonica Crantz.). Turkish Journal of Field Crops 18(2):238246.

Scapim, C.A., Oliveira, V.R., Braccini, A.D.L., Cruz, C.D., Andrade, C.A.D.B, Vidigal,M.C.G., 2000 Yield stability in maize (Zea mays L.) and correlations among the parameters of the Eberhart and Russell, Lin and Binns and Huehn models. Genetics and Molecular Biology 23(2), 387-393.

DOI: $10.1590 / \mathrm{S} 1415-$ 47572000000200025.

Shukla, G.K., 1972. Some Statistical Aspects of Partitioning GenotypeEnvironmental Components of Variability. Heredity 29, 237 245. https://doi.org/10.1038/hdy.19 72.87.

Silva, G.A.P., Gouvea, L.R.L., Verardi, C.K., Oliveira, A.L.B.D., Goncalves, P.DS., 2014. Annual growth increment and stability of rubber yield in the tapping phase in rubber tree clones: Implications for early selection. Industrial Crops and Products 52:801-808.

DOI: $10.1016 /$ j.indcrop.2013.12.01 0 .

Souza, V.Q., Pereira, P.D.S., Silva, G.O.D., Neto, R.F., Oliveira, A.C.D., 2007. Consistency of two stability analysis methods in potato. Ciencia Rural, Santa Maria, 37(3), 656-661.

St. Clair, J.B.; Kleinschmit, J. 1986. Genotype-environment interaction 
and stability in ten-year height growth of Norway spruce Clones (Picea abies Karst.). Silvae Genetica. 35(6): 177-186.

Syukur, M., Sujiprihati, S.,, Yunianti, R., Kusumah, D.A., 2014. Non paramectric stability analysis for yield of hybrid chili pepper (Capsicum annuum L.) across six different environments. J. Agron. Indonesia 42 (1) : 32 - 38.

Tai, G.C.C., 1971. Genotypic stability analysis and its application to potato regional trials. Crop Science 11, 184-190. doi:10.2135/cropsci1971.0011183 X001100020006x.

Temesgen, T., Keneni, G., Sefera, T., Jarso, M., 2015. Yield stability and relationships among stability parameters in faba bean (Vicia faba L.) genotypes. The Crop Journal 33, 258-268.

DOI: 10.1016/j.cj.2015.03.004.

Wricke, G., 1962. Über eine Methode zur Erfassung der ökologischen Streubreite in Feldversuchen. Z. Pflanzenzüchtg 47: 92-96. 